\title{
Pozitif Psikolojik Sermayenin Tükenmişlik Üzerine Etkileri: Kamu Çalışanlarına Yönelik Bir Araştırma
}

\author{
Mutlu TOKMAK*
}

\begin{abstract}
$\ddot{O} Z$
Bu çalışmanın amacı pozitif psikolojik sermaye ile tükenmişlik evreleri arasındaki ilişkiyi ortaya koymaktır. Bu amaçla pozitif psikolojik sermaye unsurlarının (öz yeterlilik, umut, psikolojik dayanıklılık, iyimserlik) tükenmişlik boyutları üzerindeki etkisini ölçmek amacıyla alan araştırması yapılmıştır. Kamu çalışanları $(N=298)$ üzerinde yapılan alan araştırmasında Maslach Tükenmişlik Envanteri ve Pozitif Psikolojik Sermaye Ölçeği kullanılmıştır. Elde edilen veriler korelasyon ve regresyon analizleri ile test edilmiştir. Araştırma sonucunda pozitif psikolojik sermaye unsurlart ile tükenmişlik boyutları arasında negatif yönlü ve anlamlı bir ilişki olduğu ortaya çıkmıştır. Özellikle pozitif psikolojik sermaye unsurlarından iyimserlik ve öz yeterlilik boyutlarının; duygusal tükenme, duyarsızlaşma ve düşük kişisel başarı hissinden oluşan tükenmişlik boyutları üzerinde azaltıcı etkisi olduğu görülmektedir.
\end{abstract}

Anahtar Kelimeler: Pozitif Psikolojik Sermaye, Tükenmişlik, Kamu Çalı̧̧anları

JEL Sinıflandırması: M10, M12, M19

\section{The Effects of Positive Psychological Capital on Burnout: A Research Aimed at Public Official}

\begin{abstract}
The purpose of this study is to reveal the relationship between positive psychological capital and burnout phases. For this purpose field study is done to measure the factors of psychological capital (self-sufficiency, hope, psychological durability, optimism) on burnout dimensions. Maslach Burnout Inventory and Positive Psychological Capital Scale have been used on the field study done over public officials $(N=298)$. The obtained data are tested by correlation and regression analyses. As a result of the research it is found out that there is avoidant and a meaningful relationship between the factors of positive psychological capital and burnout dimensions. Particularly the dimensions of optimism and self sufficiency which are the elements of positive psychology capital have the detractive effect caused by emotional burnout, desensitisation and the feeling of low personal success on burnout dimension.
\end{abstract}

Key Words: Positive Psychological Capital, Exhaustion, Public Officials

JEL Classification: M10, M12, M19

\section{GíRiş}

Teknolojik gelişmelerde yaşanan değişim çalışanların yer aldığı kurumlarda da bir takım değişiklikler meydana getirmektedir. Bazı çalışanların bu değişime ayak uyduramama çekinceleri yaşaması onların stres baskısı altında olmasına neden olmaktadır. Bu baskı belli bir süre sonra çalışanların psikolojik olarak olumsuz etkilenmelerine ve çalıştığı ortama karşı olumsuz duygular beslemesine neden olmaktadır. Akademik yazın incelendiğinde bu olumsuz

\footnotetext{
* Dr. J.Yzb., Jandarma Genel Komutanlığı, Karacabey İlçe Jandarma Komutanlığı, Bursa, mutlutokmak@hotmail.com
} 
ortamı ortadan kaldırmak veya en aza indirmek amacıyla çeşitli araştırmalar yapılmaktadır. Öncelikle ortaya çıkan olumsuzlukların ne derece olduğu tespit edilmeye çalışılmakta, durum tespiti neticesinde çözüm arayışlarına gidilmektedir.

Çalışanların iş ortamlarındaki olumsuz duyguları en aza indirgemenin yollarından bir tanesi de iş görenlerin psikolojik yapılarını geliştirmeye yönelik faaliyetlerdir. Çalışanlarda pozitif bir psikolojik yapının olması onların iş ortamlarından kaynaklanan olumsuzluklardan asgari düzeyde etkilenmelerine yardımcı olabilir.

$\mathrm{Bu}$ çalışmada işgörenlerin pozitif psikolojik sermaye yapıları ile işyerinde olumsuz davranışlar sonucu oluşan tükenmişlik sendromunun ilişkisi araştırılmaya çalışılmıştır. Bu amaçla çalışmanın ilk bölümünde, literatürde yer alan pozitif psikolojik sermaye ve tükenmişlik sendromu alanında literatür yazını taranarak elde edilen ikincil verilere yer verilmektedir. İkinci bölümde ise, Maslach Tükenmişlik Envanteri ve Pozitif Psikolojik Sermaye Ölçeği aracılığıyla elde edilen verilerin istatistik paket programı aracilığıla analiz edilmesi sonucu elde edilen bulgular yer almaktadır. Değerlendirme ve sonuç kısmında ise, literatür taraması sonucu elde edilen bilgiler ile araştırma sonucu elde edilen bulgular karşılaştırılarak değerlendirmeler yapılmakta ve sonuçlar ortaya koyularak ilgili literatüre katkı sağlanmaya çalışılmıştır.

\section{KAVRAMSAL ÇERÇEVE}

\section{A. Pozitif Psikolojik Sermaye Kavramı}

Luthans ve arkadaşları, psikolojik sermayeyi "bireyin pozitif psikolojik gelişme hali" olarak tanımlamakta ve psikolojik sermayenin kişide "Ben kimim?" sorusunun cevabını aradığını belirtmiştir (Luthans vd, 2007:3).

Psikolojik sermaye yapısının nitelikleri konusunda literatürde yapılan çeşitli çalışmalar, iş bağımlılığı (Schaufeli ve Bakker, 2004), psikolojik sağlık (Wright ve Cropanzano, 2004), psikolojik sahiplik (Avey vd., 2009), akıl, cesaret ve affetme (Luthans vd., 2007) gibi faktörlere odaklanmaktadır. Bunun yanında psikolojik sermaye yapısını en iyi açıklayan psikolojik niteliklerin umut, psikolojik dayanıklılık, iyimserlik ve öz yeterlilik olduğu öne sürülmektedir (Luthans, 2002; Luthans ve Youssef, 2004; Luthans ve Youssef, 2007; Çetin ve Basım, 2012:123). Bu kapsamda psikolojik sermaye unsurlarından umut; amaçlarına ulaşmak için azimli olması ve başarılı olmak için hedeflerine yönelebilmesi, psikolojik dayanıklılık; problemlerle ve sıkıntılarla karşılaştığında başarıya ulaşmak için ayakta kalması ve tekrar toparlanabilmesi, iyimserlik; şu an ve gelecekte daha başarılı olacağına dair pozitif yorum yapabilmesi, öz yeterlilik; bireyin zorlu görevlerde başarılı olmak için gerekli çabayı gösterebilme güvenine sahip olması şeklinde tanımlanmaktadır. $\mathrm{Bu}$ yeterliliklerin toplamı bireyin psikolojik sermayesini oluşturmaktadır. Psikolojik sermaye durağan bir yapıdan çok bireyin pozitif psikolojik gelişme durumunu yansitmaktadır (Luthans vd., 2007: 3). Psikolojik sermaye yapısını oluşturan kavramlar kısaca şu şekilde açıklanabilir: 
Umut: Umut kavramı geçmişte çoğunlukla hümanist psikoloji tarafından kullanılan bir kavram olmasına rağmen, pozitif psikoloji alanında kullanılması Snyder'in (2000) çalışmasıyla birlikte ortaya çıkmıştır. Umut, değerli amaçlar belirleyebilme ve bu amaçları elde etmede kişinin engellerin üstesinden gelebilme inancını kapsayan motivasyonel bir durumdur (Çetin ve Basım, 2012:123). Yapılan çalışmalarda umutlu kişilerin daha fazla motive oldukları ve görev alırken kendilerine daha fazla güvendikleri, ayrıca amaçlara ulaşmada engellerle karşılaştıklarında, alternatif yollara sahip oldukları ve böylece daha yüksek performans sergiledikleri ortaya çıkmıştır (Luthans ve Jensen, 2002; Peterson ve Luthans, 2003).

Psikolojik Dayanıklılı: Earvolino-Ramirez (2007) psikolojik dayanıklılığı; hastalıktan, depresyondan, değişimlerden ya da kötü durumlardan çabucak iyileşme yeteneği, kendini toparlayabilme, incindikten, gerildikten sonra eski haline kolayca dönebilme olarak tanımlamaktadır. Luthans vd. (2006)'ya göre psikolojik dayanıklılık; kişinin engel, belirsizlik ve benzeri birçok olumsuz durumla baş etme ve başarılı olma yeteneğidir.

Lyimserlik: Pozitif psikoloji hareketinin öncülerinden olan Seligman (1998:43)'a göre; insanlar, davranışlarının sebeplerini neye atfettikleri ya da nasıl açıkladıklarına bağlı olarak, iyimser ve karamsar olmak üzere sınıflandırmaktadırlar. İyimser bireyler, yaşadıkları pozitif olayları açıklarken içsel, kalıcı ve genellenebilir sebeplere; negatif olayları açılarken ise, dışsal, geçici ve duruma özgü sebeplere atıfta bulunurlar. Karamsar insanlar ise, iyimserlerin aksine, yaşadıkları pozitif olayları dışsal, geçici ve duruma özgü olarak; negatif olayları ise içsel kalıcı ve genellenebilir olarak yorumlarlar.

Öz yeterlilik: "Bireyin belli koşullarda, belirli bir görevi başarıyla yapmak için gereksinim duyduğu motivasyon, bilişsel kaynaklar ve davranış biçimini seferber etme noktasında kendisine duyduğu güven ve kendisi hakkındaki kanaati" olarak tanımlanmaktadır (Wood ve Bandura, 1989:408; Stajkovic ve Luthans, 1998:66). Bireyin, sahip olduğu yeteneğin bir işi yapabilmek için yeterli olup olmadığı hususundaki kanaati, yeteneğinin doğuştan geldiğine ya da bilgiyle geliştirilebilen beceri niteliğinde olduğuna inanması öz yeterliliğine etki etmektedir.(Wood ve Bandura, 1989:407).

\section{B. Tükenmişlik Sendromu}

Tükenmişlik kavramı ilk kez Freudenberg (1974: 159) tarafından başarısızlık, yıpranma, enerji ve güç kaybı ile bireyin iç kaynakları üzerinde karşılanmayan istekler sonucu ortaya çıkan tükenme durumu olarak tanımlanmıştır. Daha sonra 1976 yılında örgütlerde duygular üzerine çalışan Maslach bu kavrama değinmiştir (Maslach vd.,2001). Maslach ve Jackson (1981), tükenmişlikle ilgili daha sistematik çalışmalara başlamış ve tükenmişliğin işlevsel tanımını yapmışlardır. Tükenmişliği ölçmek amacı ile de Maslach Tükenmişlik Ölçeği'ni geliştirmişlerdir (Maslach vd., 2001).

Tükenmişlik; duygusal tükenme, duyarsızlaşma ve kişisel başarıda düşme olmak üzere üç aşamadan oluşan bir psikolojik sendromdur (Maslach vd., 1996; Brewer ve Clippard, 2002; Yıldız, 2012; Polatcı vd.,2014). Tükenmişlik, 
kendisini öncelikle bireyin duygusal kaynaklarını tüketmesi ile göstermekte ve bireyin duygusal anlamda tükenmesi ile sonuçlanmaktadır. Duygusal anlamda tükenen birey bir sonraki aşamada etrafindaki insanlarla olan ilişkisini sınırlandırarak psikolojik olarak insanlardan uzaklaşır. Bu şekilde duyarsızlaşma boyutu kendisini göstermiş olur. Son aşamada ise birey daha önce sergilemiş̧ olduğu olumlu davranışlarıyla şimdiki davranışları arasındaki ayrımı fark eder ve bunun sonucunda da mesafeli davranışlarının, çalıştı̆̆ kuruma ve topluma katkılarını sınırladığını düşünür. Böylece birey iş ve beşeri ilişkileri konusunda bir yetersizlik duygusu içerisine girer, işini yapma ve müşterilerine hizmet sunma konusunda, kendisini yetersiz görmeye başlar ve kişisel başarıda düşme gerçekleşmiş olur (Maslach vd., 2001: 403; Maslach , 1982). Duygusal tükenme, duyarsızlaşma ve düşük kişisel başarı hissi aşamalarından oluşan tükenmişlik sendromu boyutlarını kısaca şu şekilde açıklamak mümkündür:

Duygusal Tükenme: Tükenmişliğin bu boyutunda bireyde yorgunluk, enerji eksikliği duygusal yönden kendini yıpranmış hissetme gibi belirtiler gözlenmektedir. Duygusal tükenme literatürde tükenmişliğin en kritik ve en belirleyici boyutu olarak ifade edilmektedir. Duygusal tükenme tükenmişliğin içsel boyutu olarak görülmektedir. Duygusal tükenmişliği yaşayan kişi çalıştığ kurumda hizmet verdiği kişilere geçmişte olduğu kadar verici ve sorumlu davranmadığını düşünür, gerginlik ve engellenmişlik duygularıyla yüklü olan birey için ertesi gün yeniden işe gitme zorunluluğu büyük bir endişe kaynağ olmaktadır (Leiter ve Maslach,1988:297; Friesen ve Sarros,1989:179; Ergin, 1992:144; Ergin,1995:37; Torun,1997:47; Maslach vd.,2001:402-403; Çimen ve Ergin, 2001:169; Sweeney ve Summers, 2002:225, Singh vd.,1994:559;Ar1 ve Bal, 2008.133).

Duyarsızlaşma: Duyarsızlaşma tükenmişliğin ikinci evresidir ve kişilerarası iletişim boyutunu temsil etmektedir (Maslach ve Goldberg, 1998). Maslach ve Jackson'a (1981) göre duyarsızlaşma, tükenmişliğin en problemli boyuttur. Kişilerarası ilişkilerde meydana gelen bozulmalar, tükenmişliği bireysel bir problem olmaktan çıkarıp, örgüt geneline yayılan salgın bir hastalık haline getirmektedir. Duyarsızlaşma, bireyin hizmet sunduğu kişilere karşı birer birey olduklarını dikkate almaksızın duygudan yoksun tutum ve davranışlar sergilemesi ile kendini gösterir. Birey insancıllıktan uzaklaşmış, alaycı, küçümseyen,katı, duygusuz ve kayıtsız bir tutum içerisine girmiştir (Leiter ve Maslach,1988:297; Singh vd.,1994:559; Maslach vd.,.2001:403; Kaçmaz,2005:29).

Düşük Kişisel Başarı Hissi: Düşük kişisel başarı hissi en basit şekliyle "kişinin kendisini olumsuz değerlendirme eğiliminde olması" nı ifade etmektedir (Maslach vd., 2001:404). Birey etrafındakiler tarafından sevilmediği, müşterileriyle ilgilenmede yetersiz kaldığı, sorunlarla başa çıkamadığı, işinde başarılı olamadığı gibi duygulara kapılabilir ve bunların bir sonucu olarak da benliğine saygısı azalabilir (Yıldırım, 1996). Bu nedenle düşük kişisel başarı hissi yetersizlik, başarısızlık duygusu, düşük moral, verimlilikte ve üretkenlikte azalma, kişiler arası anlaşmazlıklar, sorunlarla başa çıkmada yetersizlik, kendine güven ve saygıda azalma gibi belirtiler içermektedir (Maslach vd., 2001:404). 
Tükenmişlik yaşayan kişi; işinde ilerleyemediğini, boşuna çalıştı̆̆ını ve zaman harcadığını düşünerek suçluluk ve yetersizlik duygularına kapılır (Silah, 2005: 163), kendisini çaresiz hissederek yeteneklerini sorgulamaya başlar ve bu durum kişisel başarıda düşüşe neden olur (Cordes vd., 1997:693).

Tükenmişlik, belirli bir dinlenme süresinden sonra ortadan kalkan geçici bir yorgunluk durumundan farklı olup, çalışma yaşamının değişik evrelerinde ortaya çıkabilmektedir (Çimen,2007:6). Tükenmişlik sendromunun üç boyutu arasındaki farkı belirlemek çok önemlidir. Tükenmişlik üzerine yapılan araştırmalar da bu üç boyutun farklı sebeplerle ortaya çıtığını ve farklı sonuçlar doğurduğunu ortaya koymuştur (Lee ve Ashforth, 1993:17). Duygusal tükenme; işle ilgili aşırı yüklenme, manevi talepler ve olumsuz çalışma koşulları gibi gerekliliklerden kaynaklanırken, duyarsızlaşma ve kişisel başarıda düşme; genellikle otorite, sosyal destek, performans değerleme ve geri besleme gibi işten kaynaklanan eksiklikler dolayısıyla oluşmaktadır (Demerouti, vd, 2000:460). Diğer yandan duygusal tükenme; işe devamsızlık yapmaya neden olurken, duyarsızlaşma ve kişisel başarıda düşme; işten ayrılmaların ve müşteri memnuniyetsizliğinin temel nedeni olarak ortaya çıkmaktadır (Schaufeli ve Enzmann 1998).

\section{Pozitif Psikolojik Sermaye ve Tükenmişlik Sendromu İlişkisi}

Psikolojik sermayenin olumlu örgütsel sonuçlarla aynı yönlü; olumsuz sonuçlarla ters yönlü ilişkileri olduğu ortaya çıkarılmıştır. Psikolojik sermaye ile örgütsel vatandaşlık davranışları, iş tatmini, örgütsel bağll1ık ve performans arasında aynı yönlü; iş stresi, işi bırakma niyeti ve sinizm gibi davranışlarla ters yönlü ilişkileri olduğu belirlenmiştir (Avey vd., 2011; Çetin vd., 2013:99).

Salanova (2004) tarafından yapılan araştırmaya göre pozitif psikolojik sermaye boyutlarından olan öz yeterlilik algısının çalışanlarda tükenmişlik algısını azalttığ1 sonucu ortaya çıkmıştır. Schaufeli ve Bakker (2004) ise yaptıkları araştırmada, pozitif psikolojik sermaye unsurlarını barındıran çalışanların, uzun çalışma saatlerine rağmen iş gereklerini yerine getirmeye çalıştıklarını ve tükenmişlik belirtileri göstermediklerini sonucuna ulaşmışlardır. Çetin vd. (2013:103) yaptığ1 araştırmada psikolojik sermaye unsurlarından, öz yeterlilik hissi yüksek olan çalışanların tükenmiş̧lik boyutlarından duyarsızlaşma ve düşük kişisel başarı hissini daha az yaşadıkları sonucuna ulaşmışlardır. Ayrıca çalışmalarında, psikolojik dayanıklılığı yüksek olan kişilerin daha az duygusal tükenmeye maruz kaldıkları da görülmüştür. Psikolojik sermayenin umut faktörünün tükenmişlik boyutlarının tamamıyla ilişkili olduğu ve duygusal tükenme, duyarsızlaşma ve düşük kişisel başarı hissini azaltıcı etkisi olduğu sonucuna ulaşmışlardır.

Yapılan araştırmalar neticesinde pozitif psikolojinin tükenmişlik üzerinde azaltıcı bir etkisi olduğu görülmektedir. Bu çalışmada da pozitif psikolojik sermaye unsurlarının çalışanların tükenmişlik duyguları üzerindeki etkisi araştırılmaktadır. Bu amaçla psikolojik sermaye unsurlarından umut, psikolojik dayanıklılık, iyimserlik ve öz yeterlilik boyutları ile tükenmişlik boyutları olan duygusal tükenme, duyarsızlaşma ve düşük kişisel başarı hissi arasındaki ilişkileri 
tespit etmek amacıyla aşağıda yer alan hipotezler geliştirilmiş ve analiz edilmeye çalışılmıştır.

Hipotez 1: Pozitif psikolojik sermaye, tükenmişlik sendromunu negatif yönde etkilemektedir.

Hipotez 2: Pozitif psikolojik sermaye unsurları (öz yeterlilik, umut, psikolojik dayanıklılı, iyimserlik) tükenmişlik sendromu boyutlarından "Duygusal Tükenmeyi” negatif yönde etkilemektedir.

Hipotez 3: Pozitif psikolojik sermaye unsurları (öz yeterlilik, umut, psikolojik dayanıklılık, iyimserlik) tükenmişlik sendromu boyutlarından "Duyarsızlaşmayı" negatif yönde etkilemektedir.

Hipotez 4: Pozitif psikolojik sermaye unsurları (öz yeterlilik, umut, psikolojik dayanıklılık, iyimserlik) tükenmişlik sendromu boyutlarından "Düşük Kişisel Başarı Hissini” negatif yönde etkilemektedir.

\section{METODOLOJİ}

\section{A. Araştırmanın Amacı ve Yöntemi}

Araştırmanın amacı pozitif psikolojik sermaye unsurlarının (umut, psikolojik dayanıklılık, iyimserlik ve öz yeterlilik) çalışanların tükenmişlik duygularının azaltılmasına ne derece katkı sunduğunu tespit etmektir. $\mathrm{Bu}$ amaçla alan araştırması yapılmıştır. Alan araştırmasında anket yöntemi seçilmiştir. Literatürde yaygın kabul gören pozitif psikolojik sermaye ölçeği (Luthans vd.,2007) ve Maslach tükenmişlik ölçeği (Maslach ve Jackson,1981)'nden yararlanılmıştır. Ölçek boyutları açıklayıcı faktör analizi ile belirlenmiştir. Araştırmanın amacına yönelik oluşturulan hipotezlerin test edilmesi için de basit doğrusal regresyon ve çoklu regresyon analizleri kullanılmıştır.

\section{B. Araştırmanın Örneklemi ve Verilerinin Toplama Aracı}

Araştırmanın ana kütlesini bir ilimizde çalışan kamu personeli oluşturmaktadır. Araştırmada basit tesadüfî örnekleme yöntemi ile katılımcılara ulaşılmış ve 298 kişiden analiz edilmeye uygun veri elde edilebilmiştir. Araştırmaya katılan katılımcı sayısı araştırma evrenini istatistikî açıdan temsil edici niteliktedir. Araştırma sadece bir ilde çalışan kamu personelini kapsadığı için genelleme yapma iddiasında değildir. Bu durum araştırmanın başlıca kısıtını oluşturmaktadır. Bu kısıta rağmen araştırmanın; çalışanlara, yöneticilere ve konu ile ilgilenen araştırmacılara önemli katkı sunacağı düşünülmektedir.

Araştırma verilerinin toplanmasında anket tekniğinden yararlanılmıştır. $\mathrm{Bu}$ kapsamda daha önce yapılmış araştırmalarda geçerliliği ve güvenilirliği test edilmiş ve literatürde kabul gören ölçeklerden yararlanılmıştır.

Pozitif Psikolojik Sermaye Ölçeği: Katılımcıların pozitif psikolojik sermayelerini ölçmek üzere, Luthans vd.,(2007) tarafından geliştirilen "Psikolojik Sermaye Anketi (PCQ-24)" kullanılmıştır. Anketin orijinali Erkuş ve Fındıklı (2013) tarafından Türkçe' ye çevrilmiş, geçerliliği ve güvenilirliği analiz edilmiştir. Uygungil (2017) tarafindan ölçekte yer alan ters ifadelerin düzenlenmesi sonucu oluşan anket formu kullanılmıştır. Ölçekte katılımcıların pozitif psikolojik sermayelerini belirlemeye yönelik öz yeterlilik, iyimserlik, umut ve psikolojik dayanıklılık olmak üzere dört boyut bulunmaktadır. Anket 
formunda, öz yeterlilik, umut, psikolojik dayanıklılık ve iyimserlik boyutlarını ölçmeye yönelik 6'şar ifade olmak üzere toplam olarak 24 ifade bulunmaktadır.

Tükenmişlik Sendromu Ölçeği: Araştırmada çalışanların tükenmişliğini ölçmek amacıyla Maslach ve Jackson (1981) tarafından geliştirilen Maslach Tükenmişlik Ölçeği kullanılmıştır. Ölçeğin Türkçe uyarlaması Ergin (1992) tarafından yapılmış, geçerlilik ve güvenilirliği analiz edilmiştir. Toplam 22 ifade ve 3 boyuttan oluşan ölçekte; 9 ifade duygusal tükenmeyi, 5 ifade duyarsızlaşmayı ve 8 ifade de düşük kişisel başarı hissini ölçmeye yöneliktir.

\section{Araştırma Bulgularının Değerlendirilmesi}

Araştırma bulgularının değerlendirilmesinde IBM SPSS 21.0 paket programı kullanılmıştır. Belirlenen hipotezler \%95 güven aralığında test edilmiştir. Pozitif psikolojik sermaye ve tükenmişlik sendromu ölçeği açıklayıcı faktör analizi aracılığıyla boyutlarına ayrılmış ve orijinal ölçekte yer alan boyut isimleri kullanılmıştır.

\section{Demografik Veriler}

Araştırmaya toplam 298 kişi katılmıştır. Katılanların \% 65,1'i (194 kişi) erkeklerden, \%34,90’u (104 kişi) Kadınlardan oluşmaktadır. Yaş değerlerine bakıldığında \%10'7'si (32 kişi) 25 yaş ve altında, \%53'ü (158 kişi) 26-31 yaş arası, \%11,4'ü (34 kişi) 32-37 yaş aras1, \%18,1'i'i (54 kişi) 38-43 yaş aras1, $\% 6,7$ 'si (20 kişi) 44 yaş ve üzerindedir. Eğitim düzeyleri incelendiğinde ise İlköğretim mezunu \%3,4 (10 kişi), Lise mezunu 26,8 (80 kişi), Önlisans mezunu 19,8’i (59 kişi), Üniversite-Lisans mezunu \%34,9 (104 kişi), Yüksek Lisans ve Doktora mezunu ise \%15,1 (45 kişi)'den oluşmaktadır. Araştırmaya katılanların \%56,4'ü (168 kişi) Evli, \%43,6'sı (130 kişi) bekârdır. Meslekteki kıdem yıllarına bakıldığında \%16,8'i (50 kişi) 1-3 yıl, \%26,8'i (80 kişi) 4-6 yıl, \%14,1 (42 kişi) 79 y1l, \%11,4 (34 kişi) 10-12 yı1, \%8,4 (25 kişi) 13-15 yı1, \%22,5 (67 kişi) ise 16 yıl ve üzeri mesleki çalışma yılına sahiptir.

\section{Güvenilirlik ve Faktör Analizi}

Pozitif psikolojik sermaye ölçeğinde yer alan 24 ifade açıklayıcı faktör analizine tabi tutulmuş umut, psikolojik dayanıklılık, iyimserlik ve öz yeterlilik olmak üzere 4 boyut oluşturulmuştur. Pozitif psikolojik sermaye ölçeğinin güvenilirlik analizi (Cronbach's Alpha) \% 93,8 olmak üzere oldukça güvenilir bulunmuştur. Umut boyutunun güvenilirlik analizi \% 76,9, psikolojik dayanıklılık $\% 83,3$, iyimserlik \% 83,0, öz yeterlilik ise \% 88,0 olarak bulunmuştur.

Tükenmişlik ölçeğinde yer alan 22 ifade açıklayıcı faktör analizine tabi tutulduğunda 3 ifadenin ölçekte yer alan boyutlarla uyumsuz olduğu tespit edilmiş ve analizden çıkartılmıştır. Tükenmişlik ölçeği güvenilirlik analizi (Cronbach's Alpha) \% 77,8 olarak güvenilir bulunmuştur.

Tükenmişlik ölçeği duygusal tükenme boyutu güvenilirlik analizi sonucu $\% 80,8$, duyarsılaşma boyutu $\% 55,5$, düşük kişisel başarı hissi boyutu $\% 72,0$ bulunmuştur. 
Tablo 1. Pozitif Psikolojik Sermaye Ölçeği Faktör Analizi Tablosu

\begin{tabular}{|l|l|l|l|l|}
\hline \multicolumn{1}{|c|}{ "Pozitif Psikolojik Sermaye Ölçeği” } & $\begin{array}{c}\text { Değişken } \\
\text { Sayısı }\end{array}$ & Ort. & S.S. & $\begin{array}{c}\text { Açıklanan } \\
\text { Varyans (\%) }\end{array}$ \\
\hline Faktör1:Öz yeterlilik & 6 & 4,31 &, 54 & 25,303 \\
\hline Faktör2: Umut & 6 & 3,94 &, 60 & 18,089 \\
\hline Faktör3: Psikolojik Dayanıklılık & 6 & 3,99 &, 65 & 11,158 \\
\hline Faktör4: İyimserlik & 6 & 3,80 &, 68 & 9,904 \\
\hline Açıklanan Toplam Varyans (\%) & 64,454 \\
\hline Kaiser-Mayer-Olkin (KMO) &, 852 \\
\hline Bartlett's Sig. Değeri &, 000 \\
\hline Ölçek Güvenilirliği (Cronbach's Alpha): & 93,8 & \multicolumn{5}{l|}{} \\
\hline
\end{tabular}

Tablo 1'de Pozitif Psikolojik Sermaye Ölçeği'ne yönelik açıklayıcı faktör analizi sonucunda ölçekte yer alan 22 ifadenin 4 faktörlü bir yap1 sergilediği tespit edilmiştir. KMO örneklem yeterlilik değeri incelendiğinde 0,852 ile örneklemin yeterli olduğu ve faktör analizinin anlamlı (Bartlett's Sig.=,000) sonuç verdiği görülmektedir.

Tablo 2. Maslach Tükenmişlik Ölçeği Faktör Analizi Tablosu

\begin{tabular}{|l|l|l|l|l|}
\hline \multicolumn{1}{|c|}{ "Maslach Tükenmişlik Ölçeği” } & \multicolumn{1}{|c|}{$\begin{array}{c}\text { Değişken } \\
\text { Sayısı }\end{array}$} & Ort. & S.S. & $\begin{array}{c}\text { Açıklanan } \\
\text { Varyans (\%) }\end{array}$ \\
\hline Faktör 1:Duygusal Tükenme & 9 & 2,45 &, 73 & 23,685 \\
\hline Faktör 2: Duyarsızlaşma & 4 & 2,41 &, 83 & 12,837 \\
\hline Faktör 3: Düşük Kişisel Başarı & 6 & 2,52 &, 68 & 12,566 \\
\hline Açılanan Toplam Varyans (\%) & 49,08 & & \\
\hline Kaiser-Mayer-Olkin (KMO) &, 696 & & \\
\hline Bartlett's Sig. Değeri &, 000 & & \\
\hline Ölçek Güvenilirliği (Cronbach's Alpha): & 77,8 &
\end{tabular}

Maslach Tükenmişlik Ölçeği'ne yönelik yapılan açılayıcı faktör analizi sonucunda 22 ifadeden oluşan orijinal ölçekten 3 ifade faktör yapısını bozduğu için çıkarılmıştır. Açıklayıcı faktör analizi sonucunda 4 faktörlü bir yapının ortaya çıtığı görülmektedir. KMO örneklem yeterlilik değerinin 0,696 olduğu ve örneklemin yeterli olduğu tespit edilmiştir. Faktör analizi sonucunda ortaya çıkan 4 boyutlu yapının anlamlı (Bartlett's Sig.=,000) olduğu görülmektedir.

\section{Araştırma Hipotezlerinin Test Edilmesi}

Araştırmanın amacına yönelik belirlenen hipotezlerin testine geçmeden önce pozitif psikolojik sermaye ve boyutları ile tükenmişlik sendromu ve boyutları arasındaki ilişkiyi belirlemeye yönelik korelasyon analizi gerçekleştirilmiştir. Korelasyon analizi sonuçlarına Tablo 3'te yer verilmektedir. 
Tablo 3:Pozitif Psikolojik Sermaye ve Tükenmişlik Korelâsyon Analizi

\begin{tabular}{|l|c|c|c|c|}
\hline & $\begin{array}{c}\text { Tükenmişlik } \\
\text { (Genel) }\end{array}$ & $\begin{array}{c}\text { Duygusal } \\
\text { Tükenme }\end{array}$ & Duyarsızlaşma & $\begin{array}{c}\text { Düşük Kişisel } \\
\text { Başarı }\end{array}$ \\
\hline $\begin{array}{l}\text { Pozitif Psikolojik } \\
\text { Sermaye (Genel) }\end{array}$ &,$- 481^{* *}$ &,$- 466^{* *}$ &,$- 118^{*}$ &,$- 316^{* *}$ \\
\hline Öz yeterlilik &,$- 380^{* *}$ &,$- 307^{* *}$ &,- 038 &,$- 391^{* *}$ \\
\hline Umut &,$- 406^{* *}$ &,$- 406^{* *}$ &,- 061 &,$- 277^{* *}$ \\
\hline Psikolojik Dayanıklılık &,$- 373^{* *}$ &,$- 346^{* *}$ &,- 088 &,$- 272^{* *}$ \\
\hline İyimserlik &,$- 507 * *$ &,$- 543^{* *}$ &,$- 205^{* *}$ &,$- 184^{* *}$ \\
\hline
\end{tabular}

${ }^{*} \mathrm{p}<0.01 ; * * \mathrm{p}<0.05$ düzeyinde anlamlıdır.

Korelasyon analizi sonuçlarına göre pozitif psikolojik sermaye ile tükenmişlik arasında negatif bir ilişki olduğu görülmektedir. Pozitif psikolojik sermaye tükenmişlik sendromunu $\% 48$ düzeyinde azaltıcı bir etkiye sahiptir. Pozitif psikolojik sermaye boyutlarından öz yeterlilik boyutu tükenmişliği \%38 düzeyinde, umut boyutu $\% 40$ düzeyinde, psikolojik dayanıkl1lı boyutu $\% 37$ düzeyinde ve iyimserlik boyutu ise \% 50 düzeyinde azaltmaktadır. Analiz sonuçlarına göre pozitif psikolojik sermayenin çalışanların tükenmişlik duygularını azaltıcı etkisi olduğu görülmektedir.

Araştırmanın amacına yönelik geliştirilen hipotezlerin değerlendirilmesine yönelik basit doğrusal regresyon ve çoklu regresyon sonuçlarına aşağıda yer verilmektedir.

Hipotez 1:Pozitif psikolojik sermaye, tükenmişlik sendromunu negatif yönde etkilemektedir.

Tablo 4: Hipotez 1'e Yönelik Basit Doğrusal Regresyon Analizi

\begin{tabular}{|c|c|c|c|c|c|c|}
\hline Bağımlı Değişken: Tükenmişlik Sendromu \\
\hline Bağımsız Değişken & $\mathbf{R}^{2}$ & $\mathbf{F}$ & $\boldsymbol{\beta}$ & $\mathbf{t}$ & $\mathbf{p}$ & $\begin{array}{c}\text { Durbin } \\
\text { Watson }\end{array}$ \\
\hline Pozitif Psikolojik Sermaye &, 232 & $89,297^{* *}$ &,- 481 & $-9,450$ &, $000^{* *}$ & 1,685 \\
\hline
\end{tabular}

$* \mathrm{p}<0,05 * * \mathrm{p}<0,01$ düzeyinde anlamlıdır.

Hipotez 1'in test edildiği Tablo 4'deki basit doğrusal regresyon analizi sonuçlarına göre tükenmişlik sendromunun $\% 23,2$ 'si $(\mathrm{p}=0,000)$ pozitif psikolojik sermaye tarafından açıklanmaktadır. Yapılan regresyon analizinde DurbinWatson istatistiği değeri 1,5-2 aralığında olup $(1,685)$, değişkenler arasında oto korelasyon olmadığ1 söylenebilir. Beta değeri $(\beta=-, 481)$ incelendiğinde negatif bir etki söz konusudur ve Hipotez 1 kabul edilir.

Hipotez 2: Pozitif psikolojik sermaye unsurları (öz yeterlilik, umut, psikolojik dayanıklılı, iyimserlik) tükenmişlik sendromu boyutlarından "Duygusal Tükenmeyi” negatif yönde etkilemektedir. 
Tablo 5: Hipotez 2'ye Yönelik Çoklu Regresyon Analizi

\begin{tabular}{|c|c|c|c|c|c|c|}
\hline \multicolumn{7}{|c|}{ Bağımlı Değişken: Duygusal Tükenme } \\
\hline Bağımsız Değişkenler & $\mathbf{R}^{2}$ & $\mathbf{F}$ & $\beta$ & $\mathbf{t}$ & $\mathbf{p}$ & $\begin{array}{l}\text { Durbin } \\
\text { Watson }\end{array}$ \\
\hline Öz Yeterlilik & \multirow{4}{*}{, 307} & \multirow{4}{*}{$32,448 * *$} &,- 042 &,- 531 &, 596 & \multirow{4}{*}{1,443} \\
\hline Umut & & &,- 104 & $-1,214$ & ,226 & \\
\hline Psikolojik Dayanıklılık & & &, 165 & 1,998 &, $047^{*}$ & \\
\hline İyimserlik & & &,- 569 & $-7,535$ &, $000 * *$ & \\
\hline
\end{tabular}

$* \mathrm{p}<0,05 * * \mathrm{p}<0,01$ düzeyinde anlamlıdır.

Tablo 5'deki regresyon modeli incelendiğinde pozitif psikolojik sermaye boyutları (Öz yeterlilik, umut, psikolojik dayanıklılık, iyimserlik) tükenmişlik alt boyutu olan "Duygusal Tükenme" üzerinde $\% 30,7(\mathrm{p}=, 000)$ oranında etkilidir. Yapılan regresyon analizinde Durbin-Watson istatistiği değeri 1,5-2 aralığına yakın olup $(1,443)$, değişkenler arasında oto korelasyon olmadığ söylenebilir. Beta değerleri incelendiğinde öz yeterlilik ve umut boyutunun bir etkisinin olmadığı, psikolojik dayanıklılık boyutunun pozitif bir yönde $(\beta=, 165)$ etkilediği görülmektedir ve hipotezin aksine bir sonuç göstermiştir. İyimserlik boyutunun ise negatif yönde $(\beta=-, 569)$ etkilediği görülmektedir. Hipotez 2 pozitif psikolojik sermaye unsurlarından öz yeterlilik boyutu için kabul edilirken diğer boyutlar açısından red edilmiştir.

Hipotez 3: Pozitif psikolojik sermaye unsurlart (öz yeterlilik, umut, psikolojik dayanıklılık, iyimserlik) tükenmişlik sendromu boyutlarından “Duyarsızlaşmayı" negatif yönde etkilemektedir.

Tablo 6: Hipotez 3'e Yönelik Çoklu Regresyon Analizi

\begin{tabular}{|c|c|c|c|c|c|c|}
\hline \multicolumn{7}{|c|}{ Bağımlı Değişken: Duyarsızlaşma } \\
\hline Bağımsız Değişkenler & $\mathbf{R}^{2}$ & $\mathbf{F}$ & $\boldsymbol{\beta}$ & $\mathbf{t}$ & $\mathbf{p}$ & $\begin{array}{l}\text { Durbin } \\
\text { Watson }\end{array}$ \\
\hline Öz Yeterlilik & \multirow{4}{*}{, 055} & \multirow{4}{*}{$4,298 * *$} &, 009 & ,099 &, 921 & \multirow{4}{*}{1,393} \\
\hline Umut & & &, 113 & 1,130 &, 259 & \\
\hline Psikolojik Dayanıklılık & & &, 067 & 695 & ,487 & \\
\hline İyimserlik & & &,- 335 & $-3,794$ &, $000 * *$ & \\
\hline
\end{tabular}

$* \mathrm{p}<0,05 * * \mathrm{p}<0,01$ düzeyinde anlamlıdır.

Hipotez 3'e yönelik oluşturulan regresyon modeli incelendiğinde pozitif psikolojik sermaye unsurlarının tükenmişlik boyutlarından "duyarsızlaşma" boyutunu açıklama oranı yaklaşık \%0,5'tir. Yapılan regresyon analizinde DurbinWatson istatistiği değeri 1,5-2 aralığına yakın olup (1,393), değişkenler arasında oto korelasyon olmadığı söylenebilir. Beta değerleri incelendiğinde iyimserlik boyutunun duyarsılaşmayı negatif yönde etkilediği $(-, 335)$ görülmektedir. Hipotez 3, iyimserlik boyutu için kabul edilirken diğer boyutlar için red edilmiştir. 
Hipotez 4: Pozitif psikolojik sermaye unsurları (öz yeterlilik, umut, psikolojik dayanıklılı, iyimserlik) tükenmişlik sendromu boyutlarından "Düşük Kişisel Başarı Hissini” negatif yönde etkilemektedir.

Tablo 7: Hipotez 4'e Yönelik Çoklu Regresyon Analizi

\begin{tabular}{|c|c|c|c|c|c|c|}
\hline \multicolumn{7}{|c|}{ Bağımlı Değişken: Düşük Kişisel Başarı Hissi } \\
\hline Bağımsız Değişkenler & $\mathbf{R}^{2}$ & $\mathbf{F}$ & $\boldsymbol{\beta}$ & $\mathbf{t}$ & $\mathbf{p}$ & $\begin{array}{l}\text { Durbin } \\
\text { Watson }\end{array}$ \\
\hline Öz Yeterlilik & \multirow{4}{*}{, 154} & \multirow{4}{*}{$13,334 * *$} &,- 400 & $-4,619$ &, $000^{* *}$ & \multirow{4}{*}{1,491} \\
\hline Umut & & & 023 &, 244 &, 807 & \\
\hline Psikolojik Dayanıklılık & & &,- 046 &,- 504 & ,615 & \\
\hline İyimserlik & & & 044 &, 530 &, 597 & \\
\hline
\end{tabular}

${ }^{*} \mathrm{p}<0,05 * * \mathrm{p}<0,01$ düzeyinde anlamlıdır.

Pozitif psikolojik sermaye unsurlarının tükenmişlik boyutlarından "Düşük Kişisel Başarı Hissi” boyutu üzerine etkisinin incelendiği regresyon modelinde R ${ }^{2}$ değerinin yaklaşık \%15 oranında olduğu görülmektedir. Modelin düşük kişisel başarı hissini açıklama oranı istatistiksel olarak anlamlıdır. Durbin-Watson istatistiği değeri 1,5-2 aralı̆̆ına yakın olup $(1,491)$, değişkenler arasında oto korelasyon olmadığı söylenebilir. Model incelendiğinde öz yeterlilik boyutunun anlamlı derecede $(\beta=-, 400)$ etkilediği görülmektedir. Öz yeterlilik boyutunun düşük kişisel başarı hissi üzerinde negatif yönde $\% 40$ düzeyinde etkisinin olduğu görülmektedir. Pozitif psikolojik sermaye unsurlarından psikolojik dayanıklılık, umut ve iyimserlik boyutlarının anlamlı bir etkisi bulunmamıştır. Hipotez 4, öz yeterlilik boyutu için kabul edilirken, diğer boyutlar için red edilmiştir.

\section{DEĞERLENDİRME VE SONUÇ}

Pozitif psikolojik sermaye, çalışanların iş ortamında psikolojik gelişim halinde olması şeklinde ifade edilmektedir. Bu durum çalışanları, iş ortamlarında karşılaştıkları olumsuz durumlarla baş etme konusunda güçlü kılmaktadır. İş yerindeki olumsuz durumların çalışanlar üzerinde tükenmişlik duygusunun yoğunlaşmasına neden olduğu açıtır. Pozitif psikoloji içerisinde olan çalışanların, problemlerin üstesinden gelme başarısı diğerlerine göre daha yüksektir.

Pozitif psikolojik sermaye ile tükenmişlik sendromu arasındaki ilişkiyi inceleyen bu çalışmada negatif yönde anlamlı ilişkiler olduğu ortaya çıkmaktadır. Pozitif psikolojik yapıya sahip olma tükenmişlik duygusunun oluşumunu yaklaşık \%48 düzeyinde azalttığı görülmektedir. Pozitif psikolojik sermaye unsurlarından iyimserlik boyutunun, tükenmişlik duygusunu azaltmada diğer boyutlara göre daha çok $(\% 50)$ etkisinin olduğu ortaya konulmaktadır. Pozitif psikolojik sermayenin tükenmişlik sendromu evrelerinden ilki olan duygusal tükenme $(\% 47)$ evresi ile ilişkisi diğerlerine göre daha yüksektir. Ocak ve Güler (2017:128) tarafından yapılan araştırmada da pozitif psikolojik sermaye ile tükenmişlik boyutlarının tamamında negatif yönlü anlamlı ilişkiler olduğu sonucun ulaşılmıştır. 
Genel olarak pozitif psikolojik sermayenin tükenmişlik üzerindeki negatif etkisinin ölçüldüğü ilk hipotezde R2 değerinin \%23 olduğu görülmektedir. Pozitif psikolojik sermaye unsurları güçlü olan çalışanların tükenmişlik sendromunun üstesinden gelmesi daha mümkündür. Çetin vd., (2013:103) tarafından yapılan araştırmada $\mathrm{da}$, bireylerin psikolojik sermayelerinin tükenmişlik duygusunu azaltıcı etkisi olduğu sonucuna ulaşılmıştır.Ocak ve Güler (2017:127) tarafından öğretmenler üzerinde yapılan araştırmada da benzer sonuçlara ulaşılmıştır.

Tükenmişlik sendromu evreleri "duygusal tükenme", "duyarsızlaşma" ve "düşük kişisel başarı hissi" üzerinde pozitif psikolojik sermaye unsurlarının ayrı ayrı etkilerinin incelendiği diğer hipotezlerde de istatistiksel olarak anlamlı sonuçlar elde edilmiştir. Duygusal tükenme üzerinde iyimserlik boyutunun etkili olduğu görülmektedir. Olumlu durumların kalıcı, olumsuz durumları ise geçici atfedildiği iyimser kişilerin duygusal tükenme ile başa çıkmada daha başarılı oldukları görülmektedir. Tükenmişlik sendromu evrelerinden duyarsızlaşma üzerinde de iyimserlik boyutunun etkisi olduğu ortaya çıkmıştır. Tükenmişlik sendromunun son evresi olan düşük kişisel başarı hissi boyutunda ise en çok etkinin öz yeterlilik yapısı kuvvetli olan kişilerde olduğu görülmektedir. Zor görevleri başarma için gerekli özgüvene sahip olan öz yeterliliği kuvvetli kişilerin daha az düşük kişisel başarı hissine kapıldıkları sonucuna ulaşılmıştır. Çetin vd., (2013:103) tarafından yapılan araştırmada da öz yeterliliğin düşük kişisel başarı hissinde negatif yönde etkisi olduğu bulgusu elde edilmiştir.

Genel olarak değerlendirildiğinde, işyerinde olumsuz durumlar karşısında tükenme aşamasına gelmiş çalışanların, bu durum ile başa çıkmasında pozitif psikolojik sermaye yapısının önemli bir etkisi olduğu görülmektedir. Özellikle iyimserlik ve öz yeterliliğe sahip bireylerin tükenmişlik sendromu evreleri ile mücadelesinde daha başarılı olacağ 1 sonucu elde edilmiştir. Çetin vd.(2013:103) tarafından kamu çalışanları üzerinde yapılan araştırmada ise öz yeterlilik ve umut boyutlarının tükenmişlik konusunda daha etkili olduğu sonucuna ulaşı1mıştır. Ocak ve Güler (2017:127), tarafindan Bosna'da öğretmenlik yapan kişiler üzerinde yapılan benzer araştırmada da iyimserlik ve psikolojik dayanıklılık boyutlarının daha çok ön plana çıktığı görülmektedir.

İşyerlerinde, çalışanlarının tükenmişlik duygularını en aza indirgemeyi arzulayan yöneticilerin, pozitif psikolojik sermaye unsurlarının geliştirilmesi için önlemler almaları gerekmektedir. Bu gelişimin eğitim ve çalışanlara psikolojik destek ile sağlanabileceği görülmektedir.

Çalışmada elde edilen sonuçların seçilen örneklem kısıtları ile birlikte değerlendirilmesi gerekmektedir. Pozitif psikolojik sermaye ve tükenmişlik üzerindeki ilişkilerin farklı sektör ve gruplarda da benzer şekilde araştırılması ve karşılaştırılmalı sonuçların elde edilmesi, hem literatür açısından hem de çalışma yaşamına katkısı açısından olumsuz sonuçlar doğuracaktır. 


\section{KAYNAKÇA}

Arı, G. S., \& Bal, E. Ç. (2008). Tükenmişlik Kavramı: Birey ve Örgütler Açısından Önemi, Yönetim ve Ekonomi, 15(1), 131-148.

Avey, J. B., Avolio, B. J., Crossley, C. D., \& Luthans, F. (2009). Psychological Ownership: Theoretical Extensions, Measurement and Relation to Work Outcomes, Journal of Organizational Behavior, 30(2), 173-191.

Avey, J. B., Reichard, R. J., Luthans, F., \& Mhatre, K. H. (2011). Meta-Analysis of The İmpact of Positive Psychological Capital on Employee Attitudes, Behaviors, and Performance, Human Resource Development Quarterly, 22(2), 127-152.

Brewer, E. W., \& Clippard, L. F. (2002). Burnout and Job Satisfaction Among Student Support Services Personnel, Human Resource Development Quarterly, 13(2), 169-186.

Cordes, C. L., Dougherty, T. W., \& Blum, M. (1997). Patterns of Burnout Among Managers and Professionals: A Comparison of Models, Journal of Organizational Behavior, 18 (6), 685701.

Çetin, F., \& Basım, H. N. (2012). Örgütsel Psikolojik Sermaye: Bir Ölçek Uyarlama Çalışması. Amme İdaresi Dergisi, 45(1), 121-137.

Çetin, F., Şeşen, H., \& Basım, H. N. (2013). Örgütsel Psikolojik Sermayenin Tükenmişlik Sürecine Etkileri: Kamu Sektöründe Bir Araştırma. Anadolu Üniversitesi Sosyal Bilimler Dergisi, 13(3), 95-108.

Çimen, M., \& Ergin, C. (2001). Türk Silahlı Kuvvetleri Sağlık Personelinin Tükenmişlik Düzeylerinin İncelenmesi, Gülhane Tip Dergisi, 43(2), 169-176.

Çimen, S. (2007), Illköğretim Öğretmenlerinin Tükenmişlik Yaşantıları Ve Yeterlik Algıları, Yayınlanmamış Yüksek Lisans Tezi, Kocaeli Üniversitesi, Sosyal Bilimler Enstitüsü, Kocaeli.

Demerouti, E., Bakker, A. B., Nachreiner, F., \& Schaufeli, W. B. (2000). A Model of Burnout and Life Satisfaction Amongst Nurses, Journal of Advanced Nursing, 32(2), 454-464.

Earvolino-Ramirez, M. (2007). Resilience: A Concept Analysis, Nursing Forum , 42 (2), 73-82).

Ergin, C. (1992). Doktor ve Hemşirelerde Tükenmişlik ve Maslach Tükenmişlik Ölçeğinin Uyarlanmas1. VII. Ulusal Psikoloji Kongresi, 22-25 Eylül 1992, Hacettepe Üniversitesi, Ankara.

Ergin, C. (1995). Akademisyenlerde Tükenmişlik ve Çeşitli Stres Kaynaklarının İncelenmesi, Hacettepe Üniversitesi Edebiyat Fakültesi Dergisi, 12(1-2).

Erkuş, A., \& Fındıklı, M. A. (2013). Psikolojik Sermayenin İs Tatmini, İs Performansı ve İsten Ayrılma Niyeti Üzerindeki Etkisine Yönelik Bir Araştırma, İstanbul Üniversitesi İsletme Fakültesi Dergisi, 42(2), 302.

Freudenberger, H. J. (1974). Staff Burn-Out, Journal of Social Issues, 30(1), 159-165.

Friesen, D., \& Sarros, J. C. (1989). Sources of Burnout Among Educators, Journal of Organizational Behavior, 10(2), 179-188.

Kaçmaz, N. (2005). Tükenmişlik (burnout) Sendromu, İstanbul Tıp Fakültesi Dergisi, 68(1).

Lee, R. T., \& Ashforth, B. E. (1993). A Further Examination of Managerial Burnout: Toward an Integrated Model, Journal of Organizational Behavior, 14(1), 3-20.

Leiter, M. P., \& Maslach, C. (1988). The Impact of Interpersonal Environment on Burnout and Organizational Commitment, Journal of Organizational Behavior, 9(4), 297-308.

Luthans, F. (2002). The Need for and Meaning of Positive Organizational Behavior., Journal of Organizational Behavior, 23 (6), 695-706.

Luthans, F., \& Jensen, S. M. (2002). Hope: A New Positive Strength for Human Resource Development. Human Resource Development Review, 1(3), 304-322.

Luthans, F., \& Youssef, C. M. (2004). Human, Social, and Now Positive Psychological Capital Management: Investing in People for Competitive Advantage, Organizational Dynamics, $33(2), 143-160$.

Luthans, F., \& Youssef, C. M. (2007). Emerging Positive Organizational Behavior, Journal of Management, 33(3), 321-349. 
Luthans, F., Avey, J. B., Avolio, B. J., Norman, S. M., \& Combs, G. M. (2006). Psychological Capital Development: Toward a Micro-Intervention. Journal of Organizational Behavior, 27(3), 387-393.

Luthans, F., Avolio, B. J., Avey, J. B., \& Norman, S. M. (2007). Positive Psychological Capital: Measurement and Relationship with Performance and Satisfaction, Personnel Psychology, 60(3), 541-572.

Luthans, F., Youssef, C. M., \& Avolio, B. J.(2007). Psychological capital: Developing the Human Competitive Edge, Oxford: Oxford University Press.

Maslach, C. (1982). Burnout: The Cost Of Caring, Ishk, Malor Books Cambridge.

Maslach, C., \& Goldberg, J. (1998). Prevention of Burnout: New Perspectives, Applied and Preventive Psychology, 7(1), 63-74.

Maslach, C., \& Jackson, S. E. (1981). The Measurement of Experienced Burnout, Journal of Organizational Behavior, 2(2), 99-113.

Maslach, C., Jackson, S.E., \& Leiter M.P.,; (1996), Maslach Burnout Inventory Manual, Third Edition, Palo Alto CA: Consulting Psychologists Press.

Maslach, C., Schaufeli, W. B., \& Leiter, M. P. (2001). Job Burnout, Annual Review of Psychology, 52(1), 397-422.

Ocak, M.\& Güler, M. (2017). Psikolojik Sermayenin Tükenmişlik Üzerine Etkisi: Görgül Bir Araştırma. Erciyes Üniversitesi İktisadi ve İdari Bilimler Fakültesi Dergisi, (49), 117-134.

Peterson, S. J., \& Luthans, F. (2003). The Positive Impact and Development of Hopeful Leaders, Leadership \& Organization Development Journal, 24(1), 26-31.

Polatçı, G., Ardıç, K, \&Türkan, G. (2014). Bağlılık Boyutlarının Tükenmişlik Boyutları Üzerindeki Etkisinin İncelenmesi, Yönetim ve Ekonomi, 21(2), 281-292.

Salanova, M. P. (2004). Engagement and Burnout: Analyzing Their Associated Patterns, Psychological Reports, 94(3), 1048-1050.

Schaufeli, W. B., \& Bakker, A. B. (2004). Job Demands, Job Resources, and Their Relationship with Burnout and Engagement: A Multi-Sample Study. Journal of organizational Behavior, 25(3), 293-315.

Schaufeli, W. B, \& Enzmann, D. (1998). The Burnout Companion to Study and Practice: A Critical Analysis. Taylor and Francis Ltd., London.

Seligman, Martin E. (1998), Learned Optimism: How to Change Your Mind and Your Life, Pocket Books, NewYork.

Silah, M. (2005). Endüstride Çalışma Psikolojisi, Seçkin Kitabevi, Eskişehir.

Singh, J., Goolsby, J. R., \& Rhoads, G. K. (1994). Behavioral and Psychological Consequences of Boundary Spanning Burnout for Customer Service Representatives, Journal of Marketing Research, 31 (4), 558-569.

Snyder, C. R. (Ed.). (2000). Handbook of Hope: Theory, Measures, and Applications, Academic press.

Stajkovic, A. D., \& Luthans, F. (1998). Social Cognitive Theory and Self-Efficacy: Goin Beyond Traditional Motivational and Behavioral Approaches, Organizational Dynamics, 26(4), 62-74.

Sweeney, J. T., \& Summers, S. L. (2002). The Effect of The Busy Season Workload on Public Accountants' Job Burnout, Behavioral Research in Accounting, 14(1), 223-245.

Torun, A. (1997). Stres ve Tükenmislik, Endüstri ve Örgüt Psikolojisi-2. Bask1, Editör: Suna Tevrüz, Türk Psikologlar Derneği ve Kalder Derneği Ortak Yayını, İstanbul.

Uygungil, S. (2017), Pozitif Psikolojik Sermaye ile Çalışan Tutumları Arasındaki Ilişskilerin Incelenmesi: Adana İlinde Bir Uygulama, Yayınlanmamış Doktora Tezi, Atatürk Üniversitesi, Sosyal Bilimler Enstitüsü, Erzurum.

Wood, R., \& Bandura, A. (1989). Impact of Conceptions of Ability on Self-Regulatory Mechanisms and Complex Decision Making. Journal Of Personality and Social Psychology, 56(3), 407. 
Wright, T. A., \& Cropanzano, R. (2004). The Role of Psychological Well-Being in Job Performance: A Fresh Look at An Age-Old Quest, Organizational Dynamics, 33(4), 338351.

Yıldırım, F. (1996), Banka Çalışanlarında İş Doyumu ve Algılanan Rol Çatışması İle Tükenmişlik Arasındaki İlişki, Yayınlanmamış Yüksek Lisans Tezi, Hacettepe Üniversitesi, Sosyal Bilimler Enstitüsü, Ankara.

Yıldız, E. (2012). Mesleki Tükenmişlik ve Rehber Öğretmenler Üzerine Bir Araştırma, Sakarya Üniversitesi Sosyal Bilimler Enstitüsü Dergisi, 33 (2), 37-61.

\section{SUMMARY}

The elements of positive psychological capital 'hope'; to reach aims being determined and to be successful aiming at its objective, psychological durability; when confronting with problems and distress to reach success keeping up and gathering strength again, optimism; commenting positively to be more successful right now and in future, self-sufficiency; it can be described as one's having confidence on making necessary effort to be successful on an uphill task. The total qualifications form one's psychological capital. Rather than being stabile pattern psychological capital reflects one's positive psychological development state (Luthans vd.,2007:3).

Exhaustion shows itself first with burnout one's emotional sources and it ends up with one's emotional burnout. The one who is exhausted emotionally become distant from the people psychologically by limiting his relationship with the people around him as a next step. In this way the dimension of desensitisation shows itself. In the final phase the person realizes the difference between previously exhibited positive behaviours and current behaviours and as a result he thinks that his reserved behaviours limit the contributions to society and the foundation he works. Therefore the person takes it for granted that he is insufficient on his profession and human relations, he considers himself inadequate to do his work and on the issue of providing service to his clients and falling on personal success becomes real. (Maslach vd., 2001:403; Maslach , 1982).

In the light of researches done it is understood that positive psychology has a detractive effect on burnout. In this study the effects of the factors of positive psychological capital on burnout emotions are being searched. For this purpose to determine the relation between the factors of psychological capital as hope, psychological durability, optimism and self-sufficiency dimensions and burnout dimensions as emotional burnout, desensitisation and low personal success feeling hypothesis are developed and tried to being analysed. "Psychological Capital Survey (PCQ-24)" which is improved by Luthans vd., (2007) is used to measure the participants' positive psychological capital. In the research to measure workers' burnout Maslach Burnout Scale is used developed by Maslach and Jackson (1981).

It emerges that there is avoidant and a meaningful relations between positive psychological capital and burnout syndrome. It is seen that having positive psychological pattern decreases the formation of burnout emotion around \%48. Optimism dimension which is the factor of positive psychological capital 
has been revealed that it has more effect (\%50) on the decrease of burnout syndrome comparing to other dimensions. Emotional burnout (\%47) the first phase of burnout syndrome of positive psychological capital has more relations comparing to the others.

Overall it is seen that the value of R2 in the first hypothesis on which the negative effect of positive psychological capital is measured on burnout is $\% 23$. The workers whose elements of positive psychology capital are strong is more possible to overcome burnout syndrome. When the effects of the elements of positive psychological capital examined separately on the phases of burnout syndrome " emotional burnout", "desensitisation" and "low of personal success feeling" it is obtained that there are statistically meaningful results in the other hypothesis as well. It is clear that optimism dimension is effective on the emotional burnout. It has been seen that the optimist ones who believe favourable situations are permanent, unfavourable situations are temporary are more successful on struggling with emotional burnout. It has also been revealed that optimism dimension has an effect on desensitisation which is the last phase of burnout syndrome. The dimension on low of personal success feeling which the last phase of burnout syndrome is seen mostly on the ones whose self-sufficiency is strong. It is inferred that the ones who get the feeling of low of personal success are the ones who has necessary self reliance and whose self-efficacy is strong to accomplish hard tasks. It is seen that to cope with this situation the pattern of psychological capital has an important effect on the employees who come to the phase of burnout in a negative case in their workplace. It is obtained as a result that specially the individuals who has optimism and self-sufficiency will be more successful to struggle with the phases of burnout syndrome. 